\title{
Gram-positive bacteria with a high DNA G+C content are characterized by a common insertion within their $23 S$ rRNA genes
}

\author{
Carsten Roller, Wolfgang Ludwig* and Karl Heinz Schleifer \\ Lehrstuhl für Mikrobiologie, Technische Universität München, D-8000 München, Germany
}

(Received 28 November 1991 ; revised 19 February 1992; accepted 2 March 1992)

\begin{abstract}
An insertion of about 100 bases within the central part of the $23 S$ rRNA genes was found to be a phylogenetic marker for the bacterial line of descent of Gram-positive bacteria with a high DNA G+C content. The insertion was present in 23S rRNA genes of 64 strains representing the major phylogenetic groups of Gram-positive bacteria with a high DNA G $+C$ content, whereas it was not found in $23 S$ rRNA genes of 55 (eu)bacteria representing Gram-positive bacteria with a low DNA G + C content and all other known (eu)bacterial phyla. The presence of the insertion could be easily demonstrated by comparative gel electrophoretic analysis of in vitro-amplified 23S rDNA fragments, which contained the insertion. The nucleotide sequences of the amplified fragments were determined and sequence similarities of at least $44 \%$ were found. The overall similarity values are lower than those of $16 S$ and 23S rRNA sequences of the particular organism. Northern hybridization experiments indicated the presence of the insertion within the mature 23S rRNA of Corynebacterium glutamicum.
\end{abstract}

\section{Introduction}

The conserved character of rRNAs is manifested in a common core structure of the homologous molecules. At the same time there is enough variation of primary and higher order structure at well known positions or regions to allow comprehensive phylogenetic investigations. In many cases signature nucleotides or sequences could be defined which are specific for phylogenetic groups of organisms (Larsen et al., 1985; Woese, 1987). Besides the primary structure signatures, the presence or absence, length and shape of higher order structure elements (helices) often correlate with phylogenetic groups. A remarkable degree of length variation can be seen, especially in $23 \mathrm{~S}$ rRNAs or rRNA genes, which results from the presence or absence of often large structure elements or sequence stretches (Larsen et al., 1985; Höpfl et al., 1989). The presently available data on 23S rRNA gene sequences indicate that there are group-specific insertions or deletions. The terms insertion and deletion are used to denote additional or missing bases in comparison to the 23S rRNA gene sequence of Escherichia coli. However, many of the large insertions are highly variable in occurrence and structure. Burgin et al. (1990) demonstrated this variability for extra sequences in 23S rRNA genes of two Salmonella species which the

\footnotetext{
* Author for correspondence. Tel. 892105 2370; fax 8921052000 ; e-mail Ludwig@mbitum2.biol.chemie.tu-muenchen.de.
}

authors called intervening sequences. These intervening sequences were found at two different positions. They can form helical structures and expand helices 25 and 45 (Höpfl et al., 1989) of premature 23S rRNA. Even within a particular strain only part of the multiple rRNA operons contain one or both of the intervening sequences. The sequence similarity between the extra elements of helix 45 of two different Salmonella species is only $77 \%$ while the overall similarity of the $23 \mathrm{~S}$ rRNA genes is $97 \%$. Recently Skurnik \& Toivanen (1991) reported intervening sequences corresponding to those of salmonella (helix 45) in the 23S rRNA genes of Yersinia enterocolitica strains. The sequence similarities between the intervening sequences of highly virulent Yersinia strains and those of Salmonella strains are higher (about $90 \%$ ) than the similarities between the corresponding sequences of highly and poorly virulent Yersinia enterocolitica strains (about $60 \%$ ). Additional sequence stretches are inserted at two homologous positions of 23S rRNA genes of the closely related species Rhodobacter capsulatus (Höpfl et al., 1988, 1989) and Rhodobacter sphaeroides (Dryden \& Kaplan, 1990). In both cases the lengths of the intervening sequences of the two species are remarkably different. It has been shown that the large intervening sequences in 23S rRNA genes of Salmonella (Burgin et al., 1990), Yersinia (Shurnik \& Toivanen, 1991) and Rhodobacter (Dryden \& Kaplan, 1990) are removed during maturation of the rRNAs. After 
Table 1. Organisms used in this study.

\begin{tabular}{|c|c|c|c|c|c|}
\hline \multirow[b]{2}{*}{ Organism } & \multirow[b]{2}{*}{ Strain* } & \multirow[b]{2}{*}{$\begin{array}{c}\text { Abbrevi- } \\
\text { ation }\end{array}$} & \multirow[b]{2}{*}{$\begin{array}{c}\text { DNA G }+ \text { C } \\
\text { content }(\%)\end{array}$} & \multicolumn{2}{|c|}{$\begin{array}{l}\text { 23S-rRNA } \\
\text { insertion }\end{array}$} \\
\hline & & & & $\begin{array}{l}\text { Length } \\
\text { (bp) }\end{array}$ & $\begin{array}{c}\mathbf{G}+\mathbf{C} \\
\text { content }(\%)\end{array}$ \\
\hline Actinomyces suis & DSM $20639^{T a}$ & Asu 39 & $55 \cdot 0$ & 116 & $48 \cdot 8$ \\
\hline Actinoplanes digitatis & DSM $43149^{\top}$ & Adi49 & $73 \cdot 0$ & 95 & $58 \cdot 0$ \\
\hline Arthrobacter citreus & DSM $20133^{\mathrm{Tb}}$ & Aci33 & $62 \cdot 9$ & 107 & $60 \cdot 7$ \\
\hline Arthrobacter citreus & ATCC $21348^{b}$ & Aci48 & ND & 108 & $50 \cdot 5$ \\
\hline Arthrobacter globiformis & DSM $20124^{\mathrm{Tb}}$ & Agl24 & $62 \cdot 0$ & 107 & 58.9 \\
\hline Arthrobacter pascens & ATCC $13346^{b}$ & $\mathrm{Ag} 146$ & ND & 107 & $60 \cdot 7$ \\
\hline Arthrobacter ramosus & $\mathrm{CCM} 1646^{\mathrm{T}}$ & Ara 46 & $62 \cdot 2$ & 106 & $63 \cdot 1$ \\
\hline Aureobacterium testaceum & DSM $20166^{\mathrm{T}}$ & Ate66 & $65 \cdot 4$ & 113 & $59 \cdot 3$ \\
\hline Aureobacterium testaceum & DSM 20526 & Ate26 & ND & 113 & $59 \cdot 3$ \\
\hline Bifidobacterium adolescentis & DSM $20083^{T b}$ & Bad83 & 58.9 & 102 & $61 \cdot 7$ \\
\hline Bifidobacterium bifidum & DSM $20456^{\mathrm{T} b}$ & Bbi56 & $58 \cdot 0$ & 100 & $70 \cdot 5$ \\
\hline Bifidobacterium infantis & DSM $20088^{T b}$ & Bin88 & $60 \cdot 8$ & 104 & $64 \cdot 2$ \\
\hline Brevibacterium linens & DSM $20425^{\top}$ & Bli25 & $63 \cdot 4$ & 102 & $57 \cdot 0$ \\
\hline Brevibacterium sp. & DSM 20165 & Bke65 & 65.9 & 99 & $60 \cdot 6$ \\
\hline Cellulomonas biazotea & DSM $20112^{\top}$ & Cbil2 & $72 \cdot 2$ & 107 & $64 \cdot 3$ \\
\hline Cellulomonas cellulans & DSM 20106 & Cce06 & $76 \cdot 0$ & 107 & $67 \cdot 0$ \\
\hline Cellulomonas fimi & DSM $20113^{T}$ & Cfil3 & $71 \cdot 7$ & 107 & 67.8 \\
\hline Cellulomonas flavigena & DSM $20109^{\top}$ & Cf109 & $72 \cdot 7$ & 107 & $61 \cdot 6$ \\
\hline Cellulomonas gelida & DSM 20110 & Cgel0 & $73 \cdot 8$ & 110 & $65 \cdot 2$ \\
\hline Cellulomonas turbata & DSM $20577^{\top}$ & Ctu77 & $70 \cdot 5$ & 106 & $62 \cdot 2$ \\
\hline Cellulomonas uda. & DSM $20107^{T}$ & Cud07 & $72 \cdot 0$ & 107 & $67 \cdot 0$ \\
\hline Clavibacter michiganense & DSM $20134^{b}$ & $\mathrm{Cmi} 34$ & $70 \cdot 7$ & 107 & $52 \cdot 7$ \\
\hline Corynebacterium callunae & DSM $20147^{T b}$ & Cca47 & $51 \cdot 2$ & 104 & $47 \cdot 7$ \\
\hline Corynebacterium glutamicum & AS $019^{c}$ & $\mathrm{Cgl} 19$ & $53 \cdot 2$ & 104 & $48 \cdot 6$ \\
\hline Corynebacterium glutamicum & DSM $1412^{c}$ & $\mathrm{Cgl14}$ & $54 \cdot 3$ & 104 & $47 \cdot 7$ \\
\hline Corynebacterium glutamicum & DSM $20137^{c}$ & $\mathrm{Cg} 137$ & $52 \cdot 9$ & 104 & $48 \cdot 6$ \\
\hline Corynebacterium glutamicum & DSM $20163^{c}$ & $\mathrm{Cgl} 63$ & $56 \cdot 0$ & 104 & $48 \cdot 6$ \\
\hline Corynebacterium glutamicum & DSM $20297^{\circ}$ & Cg197 & $54 \cdot 4$ & 104 & $47 \cdot 7$ \\
\hline Corynebacterium glutamicum & DSM $20300^{\mathrm{T} c}$ & $\mathrm{Cg} 100$ & $53 \cdot 4$ & 104 & $46 \cdot 8$ \\
\hline Corynebacterium glutamicum & DSM $20411^{\circ}$ & $\mathrm{Cgl} 11$ & $54 \cdot 0$ & 104 & $46 \cdot 8$ \\
\hline Corynebacterium glutamicum & DSM $20412^{c}$ & $\mathrm{Cg} 112$ & 53.7 & 104 & $46 \cdot 8$ \\
\hline Curtobacterium flaccumfaciens & DSM $20141^{b}$ & Cf14l & $73 \cdot 7$ & 111 & $58 \cdot 6$ \\
\hline Frankia sp. & Ag45/mut $15^{d}$ & Fsp45 & ND & 95 & $59 \cdot 0$ \\
\hline Frankia sp. & $\mathrm{AgB1} .9^{d}$ & Fsp19 & ND & 86 & $54 \cdot 9$ \\
\hline Frankia sp. & ArI. $3^{d}$ & Fsp13 & ND & 94 & $55 \cdot 6$ \\
\hline Gardnerella vaginalis & DSM $4944^{T}$ & Gra44 & $42-44$ & 102 & 43.9 \\
\hline Geodermatophilus obscurus & ATCC $20578^{\mathrm{T}}$ & Gob78 & $72 \cdot 9$ & 106 & 64.9 \\
\hline Micrococcus luteus & CСM $169^{\mathrm{T}}$ & Mlu69 & $72 \cdot 8$ & 107 & $63 \cdot 4$ \\
\hline
\end{tabular}

processing the $\mathrm{rRNAs}$ remain fragmented with in the ribosome. Fragmented $23 S$ rRNAs seem to be widespread among the Proteobacteria (Pace, 1973), but have also been reported for representatives of other bacterial phyla (Hsu et al., 1990). While for eucarya and archaea (Woese et al., 1990) true introns in rRNA genes have been described (Garret et al., 1991), none of the extra sequences in rRNA genes of (eu)bacteria known so far are introns.

Besides several smaller insertions, an additional large insertion was found in the 23S rRNA genes of some representatives of the phylogenetic group of Grampositive bacteria with a high DNA G $+C$ content, namely Frankia sp. (GenBank accession no. M55343), Micrococcus luteus (Regensburger et al., 1988; Höpfl et al., 1989), eight Streptomyces species (Pernodet et al., 1989; Stackebrandt et al., 1991; Kim et al., 1991) and 14 Mycobacterium species (Liesack et al., 1991). This insertion comprises up to 107 additional bases and is located between helices 54 and 55 of the 23S rRNA. Complete 23S rRNA sequences have been published for Frankia sp. (GenBank accession no. M55343), Micrococcus luteus (Regensburger et al., 1988), Streptomyces ambofaciens (Pernodet et al., 1989) and Streptomyces griseus (Kim et al., 1991). The similarities between the insertion sequences of the four species are $54 \%-79 \%$ in comparison with overall $23 \mathrm{~S}$ rRNA gene similarities of $81.8 \%-95.1 \%$. This again indicates, that the insertion belongs to the variable regions of the 23S rRNA gene. However, since insertions of comparable lengths were found at homologous positions of the 23S rRNA genes of only moderately related $M$. luteus, streptomycetes and mycobacteria, we decided to investigate the presence and structure of this insertion in 23S rRNA genes of various representatives of the Gram-positive bacteria with a high DNA $\mathrm{G}+\mathrm{C}$ content. 
Table 1 (continued)

\begin{tabular}{|c|c|c|c|c|c|}
\hline \multirow[b]{2}{*}{ Organism } & \multirow[b]{2}{*}{ Strain* } & \multirow[b]{2}{*}{$\begin{array}{l}\text { Abbrevi- } \\
\text { ation }\end{array}$} & \multirow[b]{2}{*}{$\begin{array}{l}\text { DNA G +C } \\
\text { content }(\%)\end{array}$} & \multicolumn{2}{|c|}{$\begin{array}{c}\text { 23S-rRNA } \\
\text { insertion }\end{array}$} \\
\hline & & & & $\begin{array}{l}\text { Length } \\
\text { (bp) }\end{array}$ & $\begin{array}{c}\mathrm{G}+\mathrm{C} \\
\text { content }(\%)\end{array}$ \\
\hline Micrococcus luteus & ATCC 10240 & Mlu40 & $65 \cdot 0$ & 107 & $63 \cdot 4$ \\
\hline Micrococcus lylae & DSM $20315^{T b}$ & Mly 15 & $67 \cdot 1$ & 109 & 57.9 \\
\hline Micrococcus nishinomiyaensis & DSM $20448^{\mathrm{T} b}$ & Mni48 & 67.8 & 103 & $56 \cdot 6$ \\
\hline Micrococcus roseus & DSM $20447^{T b}$ & Mro47 & $69 \cdot 0$ & 109 & $65 \cdot 8$ \\
\hline Micrococcus sedentarius & DSM 20317 & Mse17 & $67 \cdot 2$ & 103 & $58 \cdot 3$ \\
\hline Micrococcus sp. & MAW $2^{e}$ & Msp02 & ND & 109 & $59 \cdot 6$ \\
\hline Micrococcus varians & DSM $20033^{r}$ & Mva33 & $69 \cdot 0$ & 111 & $59 \cdot 5$ \\
\hline Mycobacterium gordonae & $-j$ & Mgo31 & ND & 105 & $59 \cdot 1$ \\
\hline Nocardia sp. & ATCC $4275^{d}$ & Nsp75 & ND & 101 & $57 \cdot 5$ \\
\hline Nocardia vaccinii & ATCC $11092^{\mathrm{Td}}$ & Nva92 & ND & 100 & $57 \cdot 1$ \\
\hline Nocardiopsis dassonvillei & DSM $43111^{\mathrm{Tb}}$ & Ndal 1 & $69 \cdot 0$ & 101 & $52 \cdot 8$ \\
\hline Nocardioides simplex & DSM $20130^{\top}$ & Nsi30 & $71 \cdot 7$ & 106 & $60 \cdot 4$ \\
\hline Propionibacterium freudenreichii & DSM $20271^{\mathrm{T}}$ & Pfr71 & $64 \cdot 0$ & 99 & $57 \cdot 7$ \\
\hline Renibacterium salmoninarum & DSM $20767^{T_{y}}$ & Rsa67 & $53 \cdot 0$ & 108 & $49 \cdot 6$ \\
\hline Rhodococcus chlorophenolicus & DSM $43826^{\text {Td }}$ & $\operatorname{Rch} 26$ & ND & 105 & $61 \cdot 8$ \\
\hline Rhodococcus erythropolis & DSM 43066 & Rer66 & $67-71$ & 100 & $54 \cdot 3$ \\
\hline Rhodococcus fascians & DSM $20669^{\mathrm{Th}}$ & Rfa69 & ND & 107 & $53 \cdot 6$ \\
\hline Streptomyces albireticuli & ATCC $19721^{\mathrm{Tb}}$ & Sal21 & ND & 101 & $62 \cdot 3$ \\
\hline Streptomyces albus & ATCC $3004^{\mathrm{T} d}$ & Sal04 & ND & 102 & 58.9 \\
\hline Streptomyces goshikiensis & ATCC $23914^{\text {Td }}$ & Sgol4 & ND & 102 & $55 \cdot 1$ \\
\hline Streptomyces griseoruber & ATCC $23919^{\gamma_{d}}$ & Sgr 19 & ND & 103 & $57 \cdot 4$ \\
\hline Streptomyces purpureus & DSM $43360^{b}$ & Spu60 & ND & 102 & 57.0 \\
\hline Streptomyces sp. & ATCC $13962^{d}$ & Ssp62 & ND & 103 & $55 \cdot 6$ \\
\hline Streptomyces sp. & ATCC $19828^{d}$ & Ssp28 & ND & 103 & $57 \cdot 4$ \\
\hline Streptomyces sp. & DSM $40225^{b}$ & Ssp25 & ND & 100 & $60 \cdot 0$ \\
\hline Streptosporangium roseum & DSM $43021^{b}$ & Sro21 & $71 \cdot 0$ & 100 & $57 \cdot 0$ \\
\hline
\end{tabular}

ND, Not determined.

* Source of cells or DNAs: $a$, N. Weiss(DSM, Braunschweig, Germany); $b$, A. Regensburger and $c$, M. Ehrmann (Technical University, München, Germany); $d$, D. Hahn (University Wageningen, The Netherlands): $e$, W. E. Kloos (State University, Raleigh, North Carolina, USA); $f$, E. Böttger (Medical University, Hannover, Germany);g, F. Fiedler (University München, Germany). ATCC, American Type Culture Collection (Rockville, MD, USA): CCM, Czechoslovak Collection of Micro-organisms (Brno, Czechoslovakia); DSM (Deutsche Sammlung von Mikroorganismen und Zellkuhuren, Braunschweig, Germany). Superscript T indicates the type strain.

\section{Methods}

Organisms and culture conditions. The organisms investigated in the present study are listed in Table 1. Cellulomonads, Nocardioides simplex DSM 20130 and Rhodococcus erythropolis DSM $43066^{\top}$ were cultured as described in the Catalogue of Strains of the DSM (Deutsche Sammlung von Mikroorganismen und Zellkulturen, Braunschweig, Germany). Cells of Renibacterium salmoninarum ATCC 33209 were kindly provided by F. Fiedler (University München, Germany), cells of Eubacterium suis DSM 20639 by N. Weiss (DSM, Braunschweig, Germany) and cells of Frankia strains by D. Hahn (Wageningen, The Netherlands).

Purification of DNA. DNAs were purified according to Marmur (1961). In addition, DNAs were kindly provided by E. Böttger (Hannover, Germany), M. Ehrmann (Technical University München, Germany), D. Hahn (Wageningen, The Netherlands), and A. Regensburger (Technical University München, Germany).

In vitro amplification of $r R N A$ genes. Either purified genomic DNA $(0 \cdot 1-1 \mu \mathrm{g})$ or whole cells (one colony) were used for in vitro amplification of rRNA genes (rDNA) applying the polymerase chain reaction technique (Saiki et al., 1988) in combination with a 23S rRNA gene-specific primer pair (23InsV, 5'-MADGCGTAGNCGAWGG$3^{\prime}$ and 23InsR, 5'-GTGWCGGTTTNBGGTA-3'). The amplification was carried out using the Taq Polymerase kit of Boehringer and a PolyChain Thermocycler (Polygen). The cycling parameters were as follows: 1 min denaturation at $95^{\circ} \mathrm{C}, 2 \mathrm{~min}$ annealing at $52^{\circ} \mathrm{C}$, and 3 min extension at $72{ }^{\circ} \mathrm{C}$. After 33 cycles, a final incubation followed for $5 \mathrm{~min}$ at $72^{\circ} \mathrm{C}$. The lengths of the amplified fragments were checked by agarose gel electrophoresis $(3 \%, w / v$, agarose) in comparison with the corresponding rDNA fragments of $E$. coli and Rhodobacter capsulatus, and a length standard (123 bp ladder, Gibco BRL).

$D N A$ and $R N A$ sequencing. The amplified rDNA fragments were separated by agarose gel electrophoresis and purified using the USBioclean MP kit (USB). The DNA fragments were either sequenced directly or after cloning (Chen \& Seeburg, 1985) in the vector pBluescript (Stratagene) using the Sequenase Version 2.0 Sequencing Kit (USB). rRNA was purified and sequenced using reverse transcriptase as described by Embley et al. (1988).

Hybridization. Southern and Northern hybridizations were carried out as described by Sambrook et al. (1989). 


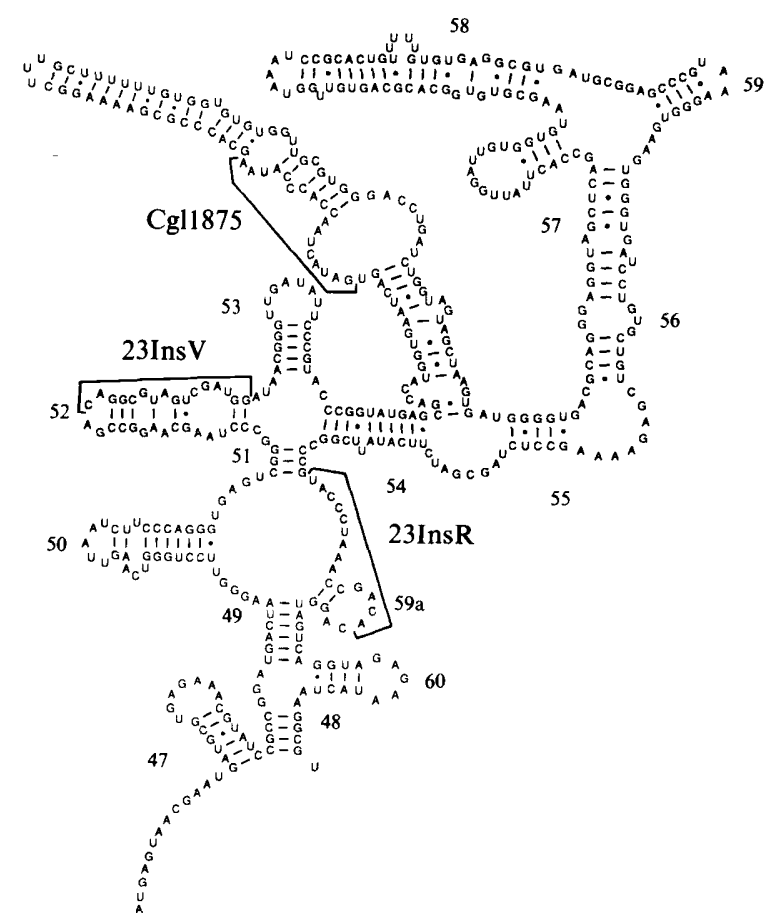

Fig. 1. Potential secondary structure model of Domain III of the 23S rRNA of C. glutamicum AS019. The insertion is shown as a secondary structure element which is located between helices 54 and 55 . The target sites of the amplification primers (23InsV, 23InsR) and of the insertion-specific hybridization probe (Cgl1875) are marked by solid lines.

\section{Results and Discussion}

The 23S rRNA genes of 64 representatives of the major phylogenetic groups within the line of descent of Grampositive bacteria with a high DNA G $+\mathrm{C}$ content were investigated with respect to presence, length and structure of an insertion in domain III (Höpfl et al., 1989), which had been detected in the corresponding genes of M. luteus (Regensburger et al., 1988; Höpfl et al., 1989) and eight Streptomyces species (Pernodet et al., 1989; Stackebrandt et al., 1991). Fig. 1 shows a potential secondary structure model of domain III of the $23 \mathrm{~S}$ rRNA of Corynebacterium glutamicum. The insertion is located between helices 54 and 55 (Höpfl et al., 1989). The part of domain III comprising helices $54-59$ is a rather variable region within the 23S rRNA (Höpfl et al., 1989) which is flanked by short conserved sequence stretches. These conserved regions of the 23S rRNA gene served as target sites for a primer pair used for the in vitro amplification of rDNA coding for this portion of the 23S rRNA. The target sites are marked in Fig. 1. The resulting rDNA fragments (about $375 \mathrm{bp}$ ) can easily be distinguished from homologous fragments lacking the approximately $100 \mathrm{bp}$ insertion by agarose gel electrophoresis. Fig. 2 is a photograph of electrophoretically separated rDNA amplificates of various Gram-positive bacteria with a high DNA $G+C$ content. Besides the length standards, a mixture of homologous in vitroamplified rDNA fragments from E. coli and R. capsulatus were included for comparison. The insertion is missing in the 23S rRNA genes of the latter organisms (Brosius et al., 1981; Höpfl et al., 1988, 1989). In comparison with the $E$. coli $23 \mathrm{~S}$ rRNA sequence a further 103 bases are deleted in the 23S rRNA of $R$. capsulatus from helices 55, 56, 58 and 59 (Höpfl et al., 1988, 1989). Therefore, the amplificate of the rDNA of $R$. capsulatus is even shorter than that of $E$. coli. The amplified rDNA fragments of all Gram-positive bacteria with a high DNA G $+C$ content comprised about 375 bp indicating the presence of about 100 extra base pairs. The insertion was detected in the 23S rRNA genes of all $64 \mathrm{Gram}-$ positive bacteria with a high DNA $\mathrm{G}+\mathrm{C}$ content investigated (Table 1), and was missing in 55 complete 23S rRNA sequences representing Gram-positive bacteria with a low DNA G $+C$ content and all (eu)bacterial phyla (Table 2). In addition, the presence of the sequence in all of five putative 23S rRNA genes of C. glutamicum was demonstrated by Southern hybridization of genomic DNA restriction fragments to a site-specific oligonucleotide Cg11875 (5'-TATTGGGTGGTTAGTATC-3') which binds within the insertion sequence. The target site is marked in Fig. 1.

In order to see whether these additional bases are inserted at a particular homologous position in the $23 \mathrm{~S}$ rRNA genes of the different organisms, the nucleotide sequences of all rDNA fragments were determined. The nucleotide sequences have been deposited at the Genbank sequence data base under accession numbers M85086 - M85141. In all 23S rRNA genes investigated the additional bases are inserted at a homologous position. The position within domain III of $23 \mathrm{~S} \mathrm{rRNA}$ is shown in the potential secondary structure model of that domain of C. glutamicum (Fig. 1). An alignment of a selection of sequences is shown in Fig. 3. The corresponding sequences of the following pairs or groups of strains are identical: Streptomyces griseoruber ATCC $23919^{\mathrm{T}}$ and Streptomyces sp. ATCC 19828; M. luteus ATCC 10240 and CCM 169 $;$ C. glutamicum DSM 20411 and DSM 20412; C. glutamicum DSM 1412 and DSM 20297; C. glutamicum AS019, DSM 20137, DSM 20163 and DSM $20300^{\mathrm{T}} ;$ Aureobacterium testaceum DSM $20166^{\mathrm{T}}$ and DSM 20526. The average length of the insertion is 104 bp and varies between 86 (Frankia sp. $\mathrm{AgB} 1.9$ ) and $116 \mathrm{bp}$ (Actinomyces suis). The similarities of the inserted sequences are $44 \%$ (Actinomyces/Bifidobacterium) and higher. Table 3 lists similarity values of the insertion sequences from representatives of the major phylogenetic groups of Gram-positive bacteria with a high DNA $\mathrm{G}+\mathrm{C}$ content. Mean values are given for 


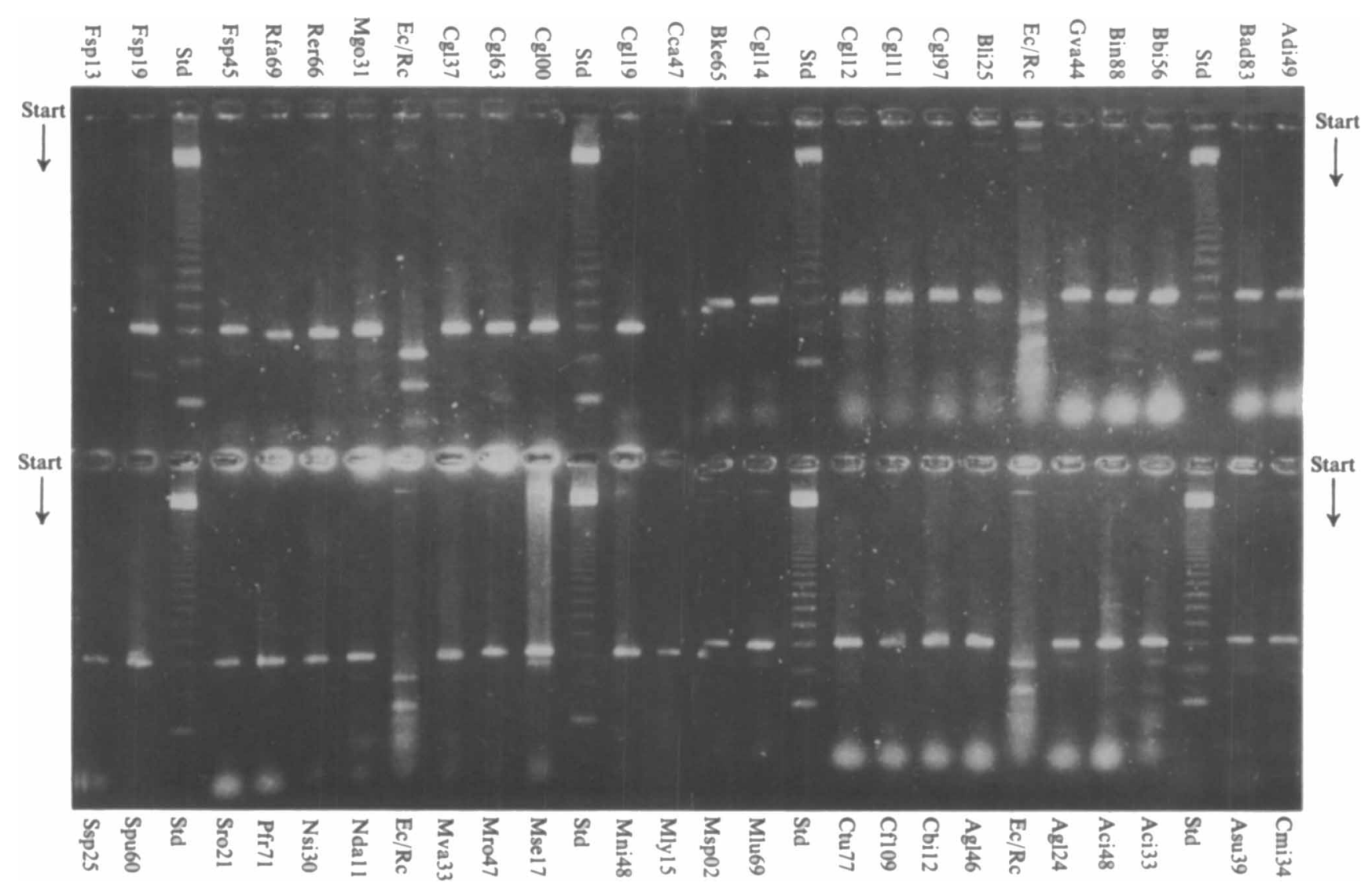

Fig. 2. Gel electrophoretic separation of in vitro-amplified rDNA fragments. The abbreviations are defined in Table 1. Std, standard size markers; Ec/Rc, mixture of amplified rDNA fragments of $E$. coli and $R$. capsulatus.

those groups of which more than one member have been investigated. The similarity values between the corresponding rRNA regions of the phylogenetic groups are in the range of $44-81 \%$ and intra-genus similarities are $61 \%$ and higher. Lowest overall sequence similarity values of complete $23 \mathrm{~S}$ or $16 \mathrm{~S}$ rRNAs from members of the major line of descent of Gram-positive bacteria with a high DNA G+C content are $70 \%$. The inserted sequence together with the flanking regions of domain III comprises the largest coherent variable part of the 23S rRNA molecule. Thus, the type of insertion investigated here is a variable element too, but in comparison with the enterobacterial insertions (Burgin et al., 1990; Skurnik \& Toivanen, 1991) the sequences are rather conserved.

Invariant and conserved residues were found within the primary structures of the insertions and are shown as a consensus sequence in Fig. 3. Some group-specific primary structure elements (signatures) can be detected: AAC (position 8-10 in Fig. 3) is unique for bifidobacteria, the combination of TA $(108,109)$ and TAACA (124-128) is characteristic for cellulomonads and the combination TT $(87,88)$ and T (119) occurs only in corynebacteria.
Potential secondary structures were derived from the insertion sequences (Fig. 4). A common pattern of helical and non-helical regions may be seen. The lengths of these regions are conserved within phylogenetic groups and vary between the groups. The overall similarity of these potential structure elements is evident. However, in vivo presence and/or stability has not been proven experimentally.

The conserved primary structure elements and the similarity of the secondary structure models indicate that these insertions in the 23S rRNA genes of Gram-positive bacteria with a high DNA G $+\mathrm{C}$ content may be derived from a single ancestral event.

Since all investigations were done at the gene level, it has to be clarified whether these secondary structure elements are stable and retained in the mature 23S rRNA, or are removed by processing, as was demonstrated for the enterobacterial intervening sequences. The presence of the insertion within cellular 23S rRNA was shown by reverse transcriptase sequencing of the particular region of the molecules from $M$. luteus (Höpfl et al., 1989) and C. glutamicum (this study). A Northern hybridization was performed with the insertion-specific probe $\mathrm{Cg} 11875$ and the amplification primer 23InsR 
Table 2. Organisms which do not contain the $23 S \mathrm{rRNA}$ gene insertion investigated in this study

\begin{tabular}{|c|c|}
\hline $\begin{array}{l}\text { Proteobacteria, } \\
\text { alpha subclass } \\
\text { Bradyrhizobium japonicum* } \\
\text { Pseudomonas diminuta* } \\
\text { Rhizobium lupini* } \\
\text { Rhodobacter capsulatus } \dagger \\
\text { Rhodobacter sphaeroides } \dagger \\
\text { Rhodopseudomonas palustris* }\end{array}$ & $\begin{array}{l}\text { Gram-positive bacteria } \\
\text { with a low DNA G +C content } \\
\text { Bacillus globisporus* } \\
\text { Bacillus licheniformis* } \\
\text { Bacillus stearothermophilus } \dagger \\
\text { Bacillus subtilis } \dagger \\
\text { Heliobacterium chlorum } \\
\text { Lactobacillus delbrueckii* }\end{array}$ \\
\hline $\begin{array}{l}\text { Proteobacteria, beta subclass } \\
\text { Pseudomonas cepacia† } \\
\text { Thiobacillus cuprinus* }\end{array}$ & $\begin{array}{l}\text { Lactococcus lactis* } \\
\text { Listeria monocytogenes* } \\
\text { Mycoplasma hyopneumoniae }\end{array}$ \\
\hline $\begin{array}{l}\text { Proteobacteria, gamma subclass } \\
\text { Acinetobacter calcoaceticus* } \\
\text { Escherichia coli } \dagger \\
\text { Klebsiella pneumoniae* } \\
\text { Leucothrix mucor* } \\
\text { Pseudomonas aeruginosa } \dagger \\
\text { Ruminobacter amylophilus } \dagger\end{array}$ & $\begin{array}{l}\text { Mycoplasma pneumoniae* } \\
\text { Pectinatus frisingensis* } \\
\text { Peptococcus niger* } \\
\text { Staphylococcus aureus* } \\
\text { Staphylococcus carnosus* } \\
\text { Streptococcus oralis } \\
\text { Streptococcus thermophilus* }\end{array}$ \\
\hline $\begin{array}{l}\text { Salmonella arizonae§ } \\
\text { Salmonella typhimurium§ }\end{array}$ & $\begin{array}{l}\text { Cyanobacteria } \\
\text { Anacystis nidulans } †\end{array}$ \\
\hline $\begin{array}{l}\text { Proteobacteria, delta subclass } \\
\text { Nannocystis exedens* } \\
\text { Stigmatella aurantiaca* }\end{array}$ & $\begin{array}{l}\text { Spirulina platensis* } \\
\text { Propionigenium } \\
\text { Propionigenium modestum* }\end{array}$ \\
\hline $\begin{array}{l}\text { Proteobacteria } \\
\text { Wolinella succinogenes* } \\
\text { CytophagalFlavobacterium/Bacteroides }\end{array}$ & $\begin{array}{l}\text { Green non-sulphur bacteria. } \\
\text { Chloroflexus aurantiacus } \\
\text { Herpetosiphon giganteus }\end{array}$ \\
\hline $\begin{array}{l}\text { Cytophaga/Flavobacterium/Bacteroides } \\
\text { Bacteroides fragilis* } \\
\text { Flexithrix dorotheae* } \\
\text { Flavobacterium odoratum } \dagger\end{array}$ & $\begin{array}{l}\text { Thermotogales } \\
\text { Thermotoga maritima } \ddagger \\
\text { Fervidobacterium islandicum* }\end{array}$ \\
\hline $\begin{array}{l}\text { Flexibacter flexibilis } \dagger \\
\text { Taxeobacter ocellatus* }\end{array}$ & $\begin{array}{l}\text { Spirochaetes } \\
\text { Leptospira interrogans } \dagger \\
\text { Spirochaeta aurantia* }\end{array}$ \\
\hline $\begin{array}{l}\text { Deinococci } \\
\text { "Deinonema" sp. }{ }^{*} \\
\text { Thermus thermophilus } \dagger\end{array}$ & $\begin{array}{l}\text { Green sulphur bacteria } \\
\text { Chlorobium vibrioforme* } \\
\text { Chlorobium limicola } \dagger\end{array}$ \\
\hline $\begin{array}{l}\text { Planctomycetes } \\
\text { Pirellula marina } \dagger\end{array}$ & $\begin{array}{l}\text { Chlamydiae } \\
\text { Chlamydia trachomatis } \S\end{array}$ \\
\hline
\end{tabular}

*W. Ludwig and others (unpublished results).

† Genbank accession nos: J01695, K02663, K00637, M10606,

M62805-M62807, M31904, M32365, X00007, X00343, X00512,

X06458, X12612, X07408, X14249, X16368, X53853-X53855.

$\ddagger$ C. R. Woese (Urbana, USA) personal communication.

$\S$ D. Lane (Boston, USA) personal communication.

which was used as a common probe for (eu)bacteria (Fig. $5)$. rRNAs of $C$. glutamicum and $R$. capsulatus were analysed in comparison. The amplified 23S rDNA fragments of $C$. glutamicum, $E$. coli and $R$. capsulatus were included for length comparison and as standards for the intensities of the hybridization signals. No major amounts of precursor nor of fragmented rRNA were detected by gel electrophoresis in the case of $C$. glutamicum. In contrast, the 23S rRNA of $R$. capsulatus was fragmented (Fig. 5a). The (eu)bacterial probe hybridized to the non-fragmented $C$. glutamicum $23 \mathrm{~S}$
rRNA, one of the $R$. capsulatus 23S rRNA fragments, and to the amplified rDNAs (Fig. 5b). The insertionspecific probe hybridized only to the non-fragmented 23S rRNA and the amplified rDNA fragments of $C$. glutamicum (Fig. 5c). The intensity of the hybridization signals of the insertion-specific probe/RNA hybrids is not diminished in comparison with that of the (eu)bacterial probe/RNA hybrids. These results indicate that the insertion is present in non-fragmented mature 23S rRNA of C. glutamicum, and that a splicing event is highly unlikely. However, the presence in mature $23 \mathrm{~S}$ 


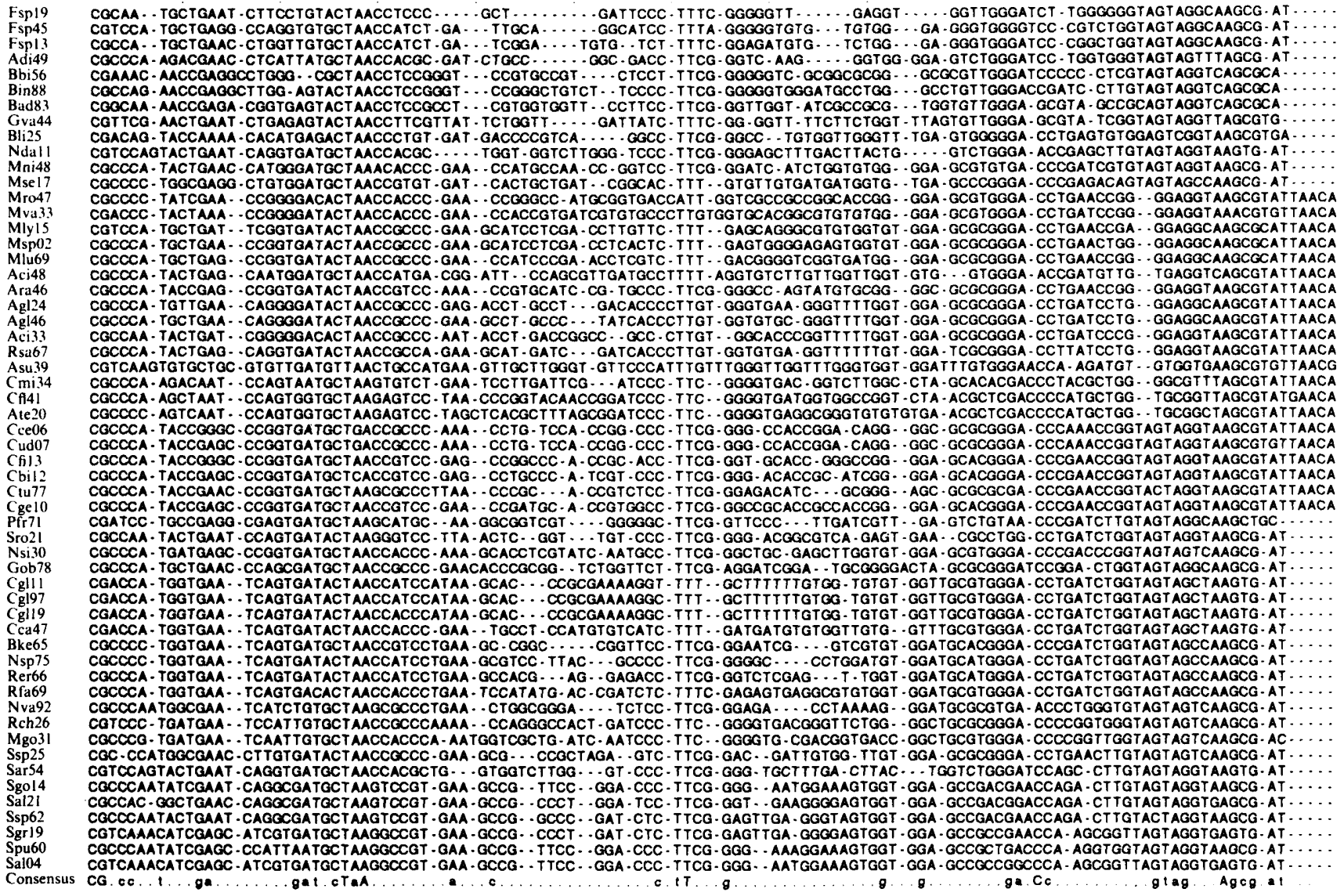

Fig. 3. Alignment of nucleotide sequence fragments containing the insertion in domain III of 23S rRNAs from Gram-positive bacteria with a high DNA G + C content. Upper case letters in the consensus sequence indicate invariant bases, lower case letters indicate bases which are invariant in at least $80 \%$ of the sequences. The alignment was done according to primary as well as secondary structure similarity. The abbreviations are defined in Table 1.

Table 3. Binary overall similarity values of the insertion sequences of Gram-positive bacteria with high $G+C$ content

Mean values are given for phylogenetic groups.

\begin{tabular}{|c|c|c|c|c|c|c|c|c|c|c|c|c|c|c|c|c|c|c|c|c|c|c|}
\hline \multirow[t]{22}{*}{01} & 02 & 03 & 04 & 05 & 06 & 07 & 08 & 09 & 10 & 11 & 12 & 13 & 14 & 15 & 16 & 17 & 18 & 19 & 20 & 21 & & \\
\hline & 44 & 54 & 52 & 45 & 46 & 51 & 52 & 51 & 54 & 44 & 51 & 43 & 52 & 53 & 52 & 51 & 52 & 45 & 46 & 45 & Actinomyces & 01 \\
\hline & & 64 & 56 & 48 & 55 & 54 & 56 & 65 & 53 & 46 & 53 & 51 & 53 & 53 & 54 & 51 & 53 & 46 & 49 & 50 & Bifidobacterium & 02 \\
\hline & & & 61 & 52 & 59 & 67 & 67 & 64 & 67 & 58 & 66 & 59 & 65 & 74 & 64 & 66 & 55 & 55 & 57 & 57 & Frankia & 03 \\
\hline & & & & 62 & 63 & 57 & 54 & 63 & 69 & 51 & 60 & 53 & 58 & 65 & 62 & 64 & 61 & 52 & 49 & 55 & Actinoplanes & 04 \\
\hline & & & & & 60 & 55 & 54 & 56 & 56 & 51 & 54 & 53 & 50 & 59 & 45 & 48 & 55 & 47 & 43 & 47 & Brevibacterium linens & 05 \\
\hline & & & & & & 64 & 55 & 62 & 63 & 61 & 64 & 58 & 62 & 63 & 53 & 57 & 60 & 46 & 49 & 51 & Nocardiopsis & 06 \\
\hline & & & & & & & 76 & 72 & 70 & 60 & 66 & 50 & 64 & 73 & 61 & 55 & 56 & 59 & 57 & 63 & Arthrobacter & 07 \\
\hline & & & & & & & & 75 & 70 & 60 & 68 & 51 & 72 & 71 & 63 & 54 & 52 & 54 & 57 & 59 & Micrococcus & 08 \\
\hline & & & & & & & & & 71 & 62 & 72 & 62 & 65 & 72 & 66 & 58 & 59 & 62 & 65 & 62 & Cellulomonas & 09 \\
\hline & & & & & & & & & & 63 & 73 & 59 & 65 & 76 & 61 & 69 & 56 & 57 & 54 & 54 & Nocardioides & 10 \\
\hline & & & & & & & & & & & 70 & 55 & 63 & 67 & 61 & 54 & 56 & 56 & 59 & 55 & Streptosporangium & 11 \\
\hline & & & & & & & & & & & & 57 & 65 & 70 & 65 & 64 & 53 & 58 & 62 & 58 & Geodermatophilus & 12 \\
\hline & & & & & & & & & & & & & 60 & 66 & 55 & 53 & 52 & 47 & 49 & 42 & Propionibacterium & 13 \\
\hline & & & & & & & & & & & & & & 78 & 63 & 63 & 54 & 49 & 53 & 51 & Corynebacterium & 14 \\
\hline & & & & & & & & & & & & & & & 66 & 67 & 59 & 55 & 57 & 61 & Rhodococcus & 15 \\
\hline & & & & & & & & & & & & & & & & 68 & 53 & 56 & 56 & 56 & Nocardia & 16 \\
\hline & & & & & & & & & & & & & & & & & 47 & 60 & 56 & 53 & Mycobacterium & 17 \\
\hline & & & & & & & & & & & & & & & & & & 53 & 56 & 59 & Streptomyces & 18 \\
\hline & & & & & & & & & & & & & & & & & & & 81 & 72 & Aureobacterium & 19 \\
\hline & & & & & & & & & & & & & & & & & & & & 73 & Curtobacterium & 20 \\
\hline & & & & & & & & & & & & & & & & & & & & & Clavibacter & 21 \\
\hline
\end{tabular}




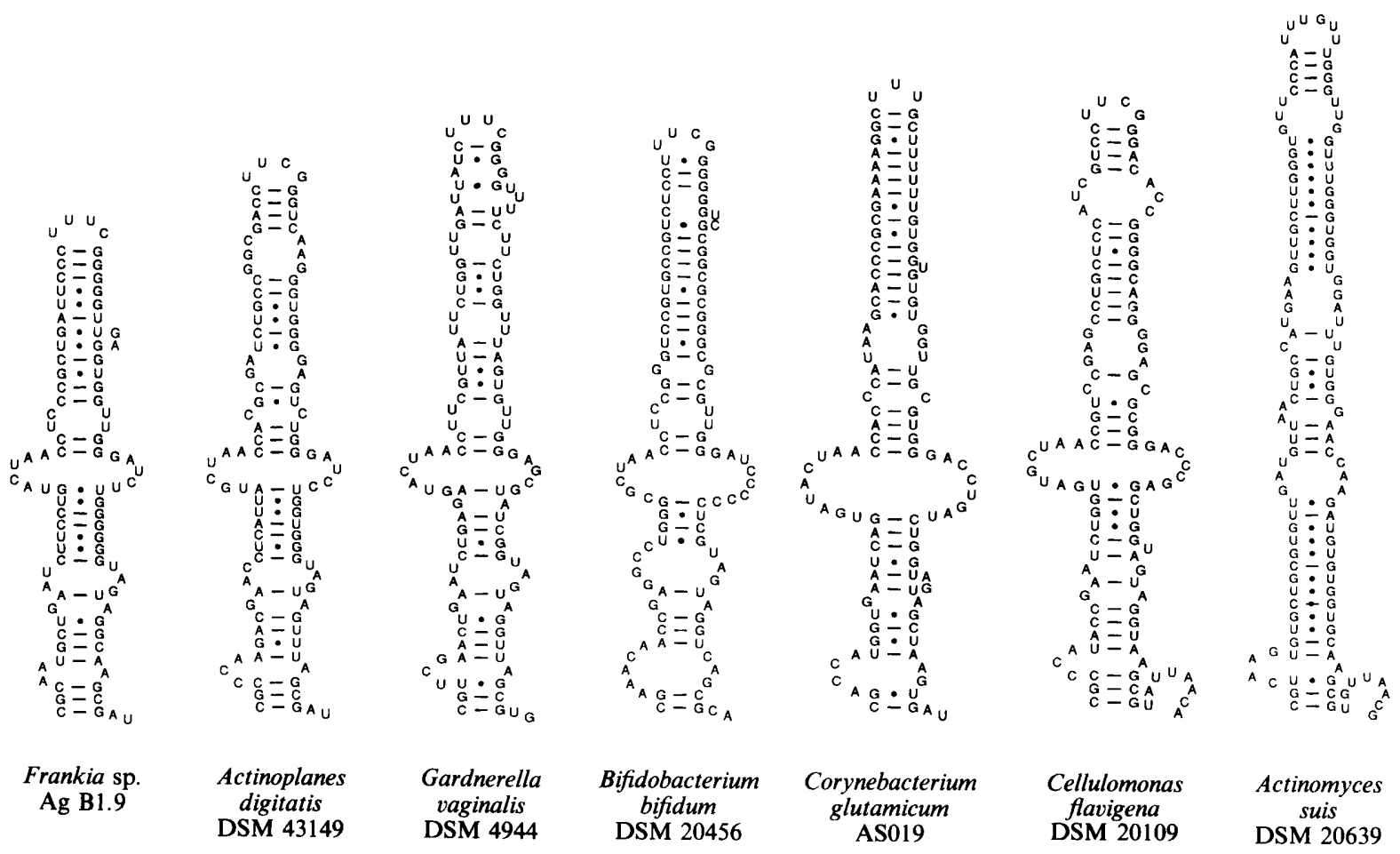

Fig. 4. Potential secondary structure models of the insertion sequences in domain III of representatives of the major phylogenetic groups of Gram-positive bacteria with a high DNA G + C content.
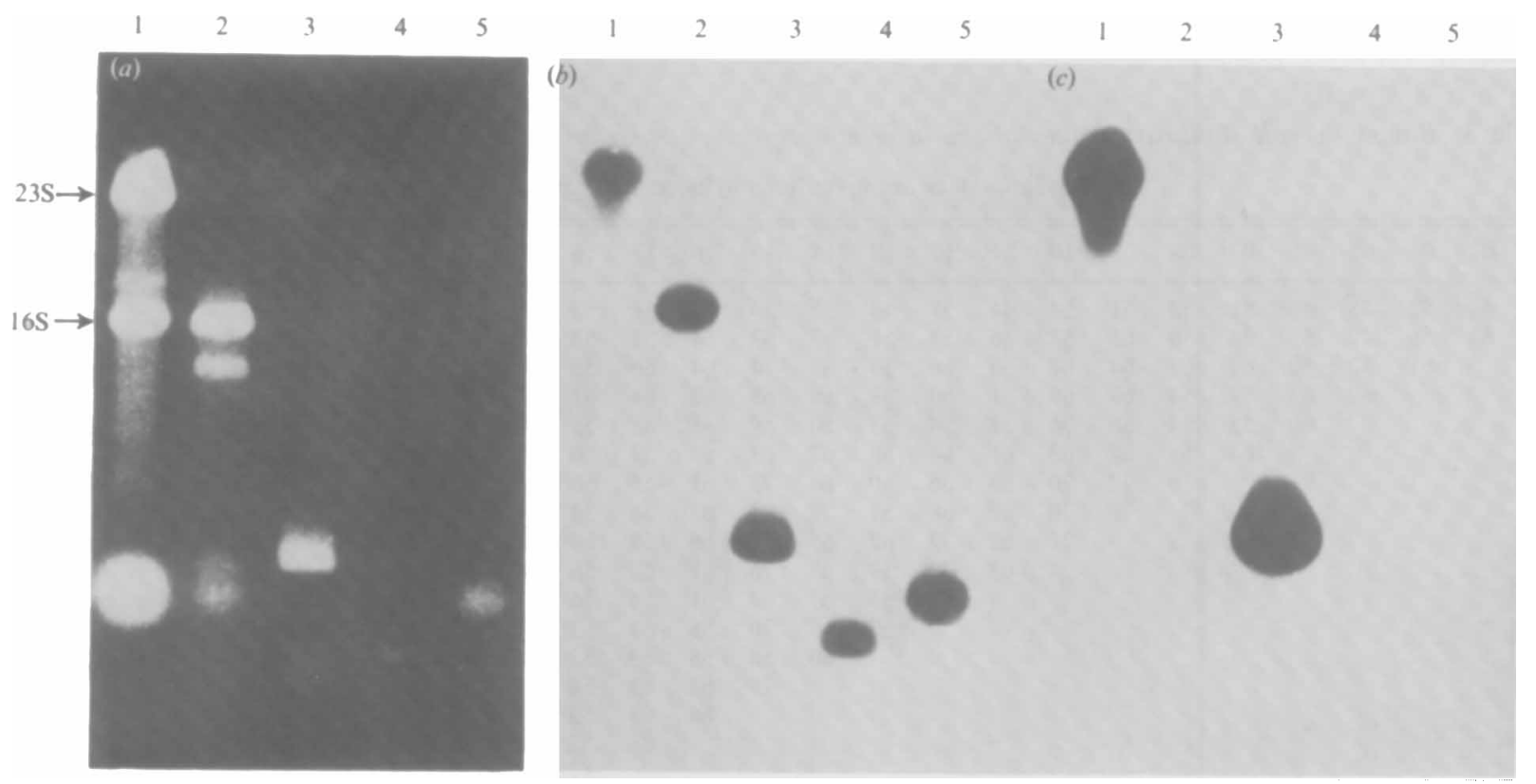

Fig. 5. Comparative gel electrophoretic and hybridization analyses of $C$. glutamicum and $R$. capsulatus 23S rRNA. (a) Gel electrophoretic separation of cellular RNAs and amplified insertion rDNA. (b) Hybridization to the (eu)bacterial probe 23InsR. (c) Hybridization to the insertion-specific probe $\mathrm{Cg} 1$ 1875. Lanes: 1, RNA of $C$. glutamicum; 2 , RNA of $R$. capsulatus; 3, amplified rDNA of $C$. glutamicum; 4, amplified rDNA of $R$. capsulatus; 5, amplified rDNA of $E$. coli. 
rRNA of other Gram-positive bacteria with a high DNA $\mathrm{G}+\mathrm{C}$ content as well as its potential position and function within ribosomes remain to be analysed.

The type of insertion found in the 23S rRNA genes of Gram-positive bacteria with a high DNA G $+C$ content seems to be substantially different from that found in all or part of the rRNA genes of a few strains of Salmonella and Yersinia (Burgin et al., 1990; Skurnik \& Toivanen, 1991). The intervening sequences described by these authors are unstable elements which are lost during the processing of precursor rRNA resulting in fragmented 23S rRNA molecules. These elements may be exchanged between the different genes within the individual and may be transferred to other strains or species (Burgin et al., 1990). It is highly likely that they were acquired very recently during the course of evolution. In contrast, the ubiquitous distribution among the various lines of descent of the Gram-positive bacteria with a high DNA $\mathrm{G}+\mathrm{C}$ content, together with the obvious structural similarities indicate that the insertion described here is a characteristic marker of this major phylogenetic group. In consequence the element may have been introduced in early evolutionary times. Since a comparable insertion could not be detected in any 23S rRNA genes of 16 representatives of Gram-positive bacteria with a low DNA G + C content, nor in those from 39 members of other bacterial phyla, it is unlikely that it is a remnant that was deleted from the other genes.

This work was supported by the Deutsche Forschungsgemeinschaft and the Fonds der Chemie.

\section{References}

Brosius, J., Dull, T. J., Sleeter, D. D. \& Noller, H. F. (1981). Gene organization and primary structure of a ribosomal RNA operon from Escherichia coli. Journal of Molecular Biology 148, 107-127.

Burgin, A. B., Parodos, K., Lane, D. J. \& Pace, N. (1990). The excision of intervening sequences from salmonella $23 \mathrm{~S}$ ribosomal RNA. Cell 60, 405-414.

Chen, E. Y. \& Seeburg, P. H. (1985). Supercoiled sequencing: a fast and simple method for sequencing plasmid DNA. DNA 4, 165-170.

DRYDEN, S. C. \& KAPLAN, S. (1990). Localization and structure analysis of the ribosomal RNA operons of Rhodobacter sphaeroides. Nucleic Acids Research 18, 7267-7277.

Embley, T. M., Smida, J. \& Stackebrandt, E. (1988). Reverse transcriptase sequencing of $16 \mathrm{~S}$ ribosomal RNA from Faenia rectivirgula, Pseudonocardia thermophila and Saccharopolyspora hirsuta, three wall type IV Actinomycetes which lack mycolic acids. Journal of General Microbiology 134, 961-966.

Garret, J., Dalgaard, J., Larsen, N., KJems, J. \& Mankin, A. S (1991). Archaeal rRNA operons. Trends in Biochemical Sciences 16, $22-25$.

HöPfl, P., Ludwig, W. \& Schleifer, K. H. (1988). Complete nucleotide sequence of a 23S ribosomal RNA gene from Rhodobacter capsulatus. Nucleic Acids Research 16, 2343.

Höpfl, P., Ludwig, W., Schleifer, K. H. \& LaRsen, N. (1989). The 23S ribosomal RNA higher order structure of Pseudomonas cepacia and other prokaryotes. European Journal of Biochemistry 185, 355-364.

Hsu, D., Pan, M.-J., Zee, Y. C. \& LefebVre, R. B. (1990). Unique ribosome structure of Leptospira interrogans is composed of four rRNA components. Journal of Bacteriology 172, 3478-3480.

Kim, E., Kim, H., Kang, K., Kho, Y. \& ParK, Y. H. (1991). Complete nucleotide sequence of a $16 \mathrm{~S}$ ribosomal RNA gene from Streptomyces griseus subsp. griseus. Nucleic Acids Research 19, 1149.

LARSEN, N., LefFers, H., KJEMS, J. \& GarretT, R. (1985). Evolutionary divergence between the ribosomal RNA operons of Halococcus morrhuae and Desulfurococcus mobilis. Systematic and Applied Microbiology 7, 49-58.

Liesack, W., Sela, S., Beresvier, H., Pitulla, C. \& Stackebrandt, E. (1991). Compiete nucleotide sequence of the Mycobacterium leprae 23S and 5S rRNA genes plus flanking regions and their potential in designing diagnostic oligonucleotide probes. FEBS Letters 281, 114-118.

MarmuR, J. (1961). A procedure for the isolation of DNA from microorganisms. Journal of Molecular Biology 3, 208-218.

PACE, N. R. (1973). Structure and synthesis of ribosomal ribonucleic acid of prokaryotes. Microbiological Reviews 51, 77-129.

Pernodet, J.-L., Boccard, F., Alegre, M.-T., Gagnat, J. \& GUÉRINEAU, M. (1989). Organization and nucleotide sequence of a ribosomal RNA gene cluster from Streptomyces ambofaciens. Gene 79, 33-46.

Regensburger, A., Ludwig, W. \& Schleifer, K. H. (1988). Complete nucleotide sequence of a 23S ribosomal RNA gene from Micrococcus luteus. Nucleic Acids Research 16, 2344.

Saiki, R. K., Gelfand, D. H., Stoffel, S., Scharf, S. J., Higuchi, R., Horn, G. T., Mullis, K. G. \& Ehrlich, E. H. (1988). Primer directed enzymatic amplification of DNA with a thermostable DNA polymerase. Science $99,487-491$.

Sambrook, J., Fritsch, E. F. \& Maniatis, T. (1989). Molecular Cloning. A Laboratory Manual, 2nd edn. Cold Spring Harbor, NY: Cold Spring Harbor Laboratory.

SkURNIK, M. \& ToIVANEN, P. (1991). Intervening sequences (IVSs) in the 23S ribosomal RMNA genes of pathogenic Yersinia enterocolytica strains. The IVSs in Y. enterocolytica and Salmonella typhimurium have a common origin. Molecular Microbiology 5, 585-593.

Stackebrandt, E., Witt, D., Kemmerling, C., KropPenstedt, R. \& LIESACK, W. (1991). Designation of streptomycete $16 \mathrm{~S}$ and $23 \mathrm{~S}$ rRNA-based target regions for oligonucleotide probes. Applied and Environmental Microbiology 57, 1468-1477.

WOESE, C. R. (1987). Bacterial evolution. Microbiological Reviews 51, 221-271.

Woese, C. R., Kandler, O. \& Wheelis, M. L. (1990). Towards a natural system of organisms: proposals for the domains Archaea, Bacteria and Eucarya. Proceedings of the National Academy of Sciences of the United States of America 87, 4576-4579. 